\title{
Application Of Active Range Of Motion In Nursing Services And CareIn Elderly With Stroke
}

\author{
Ayu Larasati $1^{*}$, Ricky Riyanto Iksan ${ }^{2}$, Buntar Handayani ${ }^{3}$ \\ Akademi Keperawatan Pelni Jakarta1,2,3 \\ *Corresponding Autor : Ayuandinilarasati.05@gmail.com
}

\begin{abstract}
ABSTRAK
Stroke is a big problem for the elderly in low-income countries (developing countries) than in high-income countries (developed countries). The Range of Motion Active stroke intervention is one of the non-pharmacological therapy efforts, exercises that are carried out to maintain or improve the level of perfection and the ability to move joints normally and completely to increase muscle mass and muscle tone. This study aims to identify the effect of providing Active Range of Motion exercise therapy in nursing services and care for the elderly with stroke problems. This type of research is a case study design research, which is a form of research (inquiry) or case studies and interventions about a problem that has a specificity (particularity). The results showed that the provision of Active Range of Motion was scored with the Pretest and Posttest scores. There is a change in the value of muscle strength in elderly stroke after being given Active Range of Motion exercise from the value of the muscle strength scale 2 to 3, 3 to 4 , and 4 to 5 . with data on the characteristics of stroke patients, namely age, gender and activities such as rarely exercising and not exercising repeatedly, this shows that the more frequent Active Range of Motion exercises can affect the assessment of muscle strength in stroke patients.
\end{abstract}

Keywords: Muscle Strength, Elderly, Active ROM, Stroke, Muscle Tonus

\section{INTRODUCTION}

Stroke is a big problem for the elderly in low-income countries (developing countries) than in high-income countries (developed countries). Stroke is the number one cause of physical or mental disability worldwide. Stroke is a functional brain disorder that occurs suddenly with focal or global clinical signs and symptoms lasting more than 24 hours. According to (World Health Organization 2016). Strokes are more common in developing countries because more than $81 \%$ of deaths from stroke occur in low-income countries and the percentage of premature deaths rises to $94 \%$ in the elderly. WHO (2018) every year 15 million people worldwide experience a stroke. About five million suffer from permanent paralysis. In Southeast Asia, there are 4.4 million people who have had a stroke. Indonesia is a country with the highest stroke mortality 


\section{COMPREHIENSTVE HEALHH CRRE-}

rate in Southeast Asia.

Results The prevalence of stroke in Indonesia based on doctor's diagnosis is $10.9 \%$ per mile, the highest with a percentage of $14.7 \%$ in East Kalimantan, the Special Region of Yogyakarta at $14.6 \%$ and the lowest position in Papua with a percentage of $4.1 \%$. As for the Special Capital Region of Jakarta itself, it gets a percentage of $12.2 \%$ And for stroke prevalence data in the population in Indonesia based on a doctor's diagnosis, the largest is at the age of 75 years and over, namely (50.2\%), aged 65-74 years with a percentage of $(45,3 \%)$ then the third position at the age of 55-64 years with a percentage (32.4\%), (14.2\%) at the age of 45-54 years, (3.7\%) at the age of 35-44 years, $(1,4 \%)$ at the age of $25-34$ years, and the lowest percentage $(0.6 \%)$ at the age of $15-24$ years. (Ministry of Health of the Republic of Indonesia in 2018).

Signs and symptoms of a stroke are known by the abbreviation "Secepat Ke Hospital" or Asymmetrical smile, Movement of half of the body weakens suddenly, Speaks sluggishly or suddenly can't speak, Numbness or numbness, Myopic, Severe headache that appears suddenly sudden onset and impaired balance function. The risk factors for this disease are age, gender, parental history, ethnicity or race, hypertension, heart disease, diabetes mellitus, smoking, alcohol and obesity. (Ministry of Health of the Republic of Indonesia, 2017).

One of the impacts of most elderly stroke patients is experiencing paralysis and muscle weakness due to sensory and motor disturbances as well as temporary or permanent loss of brain function in movement, thinking, memory, speech, or sensation. While for stroke patients walking activity is very important. to support everyday. One of the interventions provided is range of motion exercise therapy or Active Range of Motion (Irawan \& Sondang, 2015).

Various efforts have been made to prevent and control stroke by the Ministry of Health of the Republic of Indonesia, namely by increasing physical activity, healthy living behavior, environmental quality, education on healthy living, providing healthy food and accelerating nutrition improvement. The government has also developed human resources and financing systems such as the BPJS program and strengthened networks and monitoring such as the Knock Door ServeWith Heart. Program to monitor the level of health in the working area of the health center and evaluate its implementation. 


\section{COMPREHENSIVE HEALH CARE}

The Range of Motion Active stroke intervention is one of the exercise therapy efforts carried out to maintain or improve the level of perfection and the ability to move joints normally and completely to increase muscle mass and muscle tone. The provision of Active Range of Motion exercises is carried out for 30 minutes twice a day to increase muscle strength and provide physical health for the elderly with stroke. The advantages of Range of Motion Therapy are useful for determining the value of the ability of bones and muscles to move, assessing bones and joints, muscles, preventing joint stiffness and improving blood circulation.(Nurtanti \& Ningrum, 2018).

The results of research conducted by Kristen (2017). The effect of Range Of Motion Exercise on muscle strength in stroke patients in the Sidotopo Public Health Center Surabaya, this study used the Pre-Experimental One-Group Pre-Post Test Design method, the results after the study showed that there was an increase in muscle strength from a scale of 3 to a scale of 4 and from a scale of 4 to a scale of 5 .

The results of research conducted by Nurtanti \& Ningrum (2018) from the nursing journal Akper GSH with the title of the effectiveness of active Range Of Motion (ROM) on increasing muscle strength in stroke patients, with qualitative research methods with a descriptive status approach. from a scale of 2 which is able to move muscles or weak parts to a scale of 3 which is able to move muscles with minimal resistance.

The results of research conducted by Ningsih \& Nusontoro (2019) with the title nursing care for non-hemorrhagic stroke patients by fulfilling the needs of activity and rest, with a descriptive method using a case approach. The results of the research are changes in muscle strength after therapy. From the results of a preliminary study conducted in the Puskesmas area of Jatipulo II Village, Palmerah District, 192,103 people with the 5 most diseases, one of which was stroke, was 13 people. Data from the survey in the Jatipulo II Village Health Center, Palmerah District, which started from November to December 2019 with a total of 315 families, the fourth highest disease distribution data was stroke with 13 people. (Secondary Data Survey Results in RW 07 Sub-district Jatipulo Sub-District, Palmerah District, 2019).

Based on the description above, researchers are interested in compiling and analyzing how "Active Range of Motion Exercise Interventions in Nursing Services and Care for Elderly With Stroke Problems in the Jatipulo Health Center, West Jakarta" to 


\section{COMPREHENSTV HEALHH CARE-}

deal with stroke problems.

\section{MATERIAL AND METHODS}

This type of research is a case study design research, which is a form of research (inquiry) or case studies and interventions about a problem that has a specificity (particularity) with the aim of studying intensively about social units such as associations, individuals and groups, families and groups. even the general public. According to (Basuki in 2017). In this study, researchers conducted an active Range of Motion exercise therapy intervention in four elderly people with stroke, namely that all four patients were given active Range of Motion exercise therapy.

In this study, researchers conducted an active Range of Motion exercise intervention in nursing care and care for elderly stroke patients with the same characteristics, namely 4 clients were both given active Range of Motion exercise for 30 minutes, every $2 \mathrm{x}$ a day for 7 days. The research results meet the requirements for testing, the researchers have met the proposal test and passed the ethical test of this research.

\section{RESULTS}

Table 1. Characteristics of Respondents $(n=4)$ with Muscle Strength Scale Before being given Active ROM Intervention Exercises

\begin{tabular}{ccccc}
\hline Respondent & Age & Gender & Suffer a Stroke & Muscule strength scale \\
\hline R1 & 63 & Man & 6 Months & 3 \\
\hline R2 & 65 & Man & 8 Months & 3 \\
\hline R3 & 60 & Women & 1 Years & 2 \\
\hline R4 & 72 & Women & 8 Months & 2
\end{tabular}

In accordance with the main reference journal used, the inclusion criteria of the respondents are the elderly aged 60 years and over, the elderly with stroke patients, the elderly who can perform Active Range of Motion, can communicate well. The scale of muscle strength in the elderly shows that female respondents with an average value of 2 and male respondents with an average value of 3 . During the intervention and implementation, the elderly were very cooperative. 
Table 2. Characteristics of Muscle Strength Scale of Respondents $(n=4)$ Before and After being givenActive ROM Intervention Exercises

\begin{tabular}{|c|c|c|c|}
\hline Respondent/Time & $\begin{array}{l}\text { Before doing } \\
\text { Active ROM }\end{array}$ & $\begin{array}{l}\text { After doing } \\
\text { Active ROM }\end{array}$ & Description \\
\hline \multicolumn{4}{|l|}{ Respondent 1} \\
\hline $\begin{array}{l}9.00 \mathrm{am} \\
4.00 \mathrm{pm}\end{array}$ & 3 & 3 & $\begin{array}{l}\text { No increase, Assess } \\
\text { muscle strength }\end{array}$ \\
\hline $\begin{array}{l}\text { Respondent } 2 \\
9.30 \mathrm{am} \\
4.30 \mathrm{pm} \\
\end{array}$ & 3 & 3 & $\begin{array}{c}\text { No increase, Assess } \\
\text { muscle strength }\end{array}$ \\
\hline $\begin{array}{c}\text { Respondent } 3 \\
10.00 \mathrm{am} \\
17.00 \mathrm{pm} \\
\end{array}$ & 2 & 2 & $\begin{array}{l}\text { No increase, Assess } \\
\text { muscle strength }\end{array}$ \\
\hline $\begin{array}{l}\text { Respondent } 4 \\
10.00 \mathrm{am} \\
17.00 \mathrm{pm}\end{array}$ & 2 & 2 & $\begin{array}{l}\text { No increase, Assess } \\
\text { muscle strength }\end{array}$ \\
\hline
\end{tabular}

The first day before active ROM exercise, the average value of muscle strength2 and 3. After active ROM exercise, there was no significant increase in muscle strength on the first day.

Table 3. Characteristics of Muscle Strength Scale of Respondents $(n=4)$ Before and After being givenActive ROM Intervention Exercises

\begin{tabular}{lccl}
\hline \multirow{2}{*}{ Respondent/Time } & \multicolumn{2}{c}{ Muscle Strength Scale } & Description \\
\cline { 2 - 3 } & $\begin{array}{c}\text { Before doing Active } \\
\text { ROM }\end{array}$ & $\begin{array}{c}\text { After Doing Active } \\
\text { ROM }\end{array}$ & \\
\hline $\begin{array}{l}\text { Responden 1 } \\
9.00 \mathrm{am}\end{array}$ & 3 & 3 & $\begin{array}{l}\text { No increase, Assess } \\
\text { muscle strength }\end{array}$ \\
$4.00 \mathrm{pm}$ & 3 & 3 & $\begin{array}{l}\text { No increase, Assess } \\
\text { muscle strength }\end{array}$ \\
\hline $\begin{array}{l}\text { Responden } \\
9.30 \mathrm{am}\end{array}$ & & & $\begin{array}{l}\text { There is an } \\
4.30 \mathrm{pm}\end{array}$ \\
\hline $\begin{array}{l}\text { Responden } 3 \\
10.00 \mathrm{am}\end{array}$ & 2 & 3 & $\begin{array}{l}\text { increase,Assess } \\
\text { muscle strength }\end{array}$ \\
$05.00 \mathrm{pm}$ & & & $\begin{array}{l}\text { No increase, Assess } \\
\text { muscle strength }\end{array}$ \\
\hline $\begin{array}{l}\text { Responden } 4 \\
10.00 \mathrm{am}\end{array}$ & & & \\
$05.00 \mathrm{pm}$ & 2 & 2 & \\
\hline
\end{tabular}

The second day showed that from 4 respondents before active ROM exercise the average value of muscle strength 2 and 3 . After active ROM exercise did not experience a significant increase in muscle strength only respondent 3 , namely from a scale of 2 to 3. 
Table 4. Characteristics of Muscle Strength Scale of Respondents $(n=4)$ Before and After being givenActive ROM Intervention Exercises

\begin{tabular}{|c|c|c|c|}
\hline \multirow[t]{2}{*}{ Respondent/Time } & \multicolumn{2}{|c|}{ Muscle Strength Scale } & \multirow[t]{2}{*}{ Description } \\
\hline & $\begin{array}{c}\text { Before doing Active } \\
\text { ROM }\end{array}$ & $\begin{array}{c}\text { After Doing Active } \\
\text { ROM }\end{array}$ & \\
\hline $\begin{array}{l}\text { Responden } 1 \\
9.00 \mathrm{am} \\
4.00 \mathrm{pm}\end{array}$ & 3 & 4 & $\begin{array}{l}\text { There is an increase, } \\
\text { Assess muscle } \\
\text { strength }\end{array}$ \\
\hline $\begin{array}{l}\text { Responden } 2 \\
9.30 \mathrm{am} \\
4.30 \mathrm{pm}\end{array}$ & 3 & 4 & $\begin{array}{l}\text { There is an increase, } \\
\text { Assess muscle } \\
\text { strength }\end{array}$ \\
\hline $\begin{array}{l}\text { Responden } 3 \\
10.00 \mathrm{am} \\
05.00 \mathrm{pm}\end{array}$ & 2 & 3 & $\begin{array}{l}\text { There is an increase, } \\
\text { Assess muscle } \\
\text { strength }\end{array}$ \\
\hline $\begin{array}{l}\text { Responden } 4 \\
10.00 \mathrm{am} \\
05.00 \mathrm{pm} \\
\end{array}$ & 2 & 3 & $\begin{array}{l}\text { There is an increase, } \\
\text { Assess muscle } \\
\text { strength }\end{array}$ \\
\hline
\end{tabular}

The third day showed that from 4 respondents before active ROM exercise the average value of muscle strength 2 and 3. After active ROM exercise, respondents 1 and 2 experienced an increase in muscle strength value from scale 3 to scale 4 . Respondent 4 experienced an increase in muscle strength value from scale 2 becomes a scale of 3 .

Table 5. Characteristics of Muscle Strength Scale of Respondents $(n=4)$ Before and After being givenActive ROM Intervention Exercises

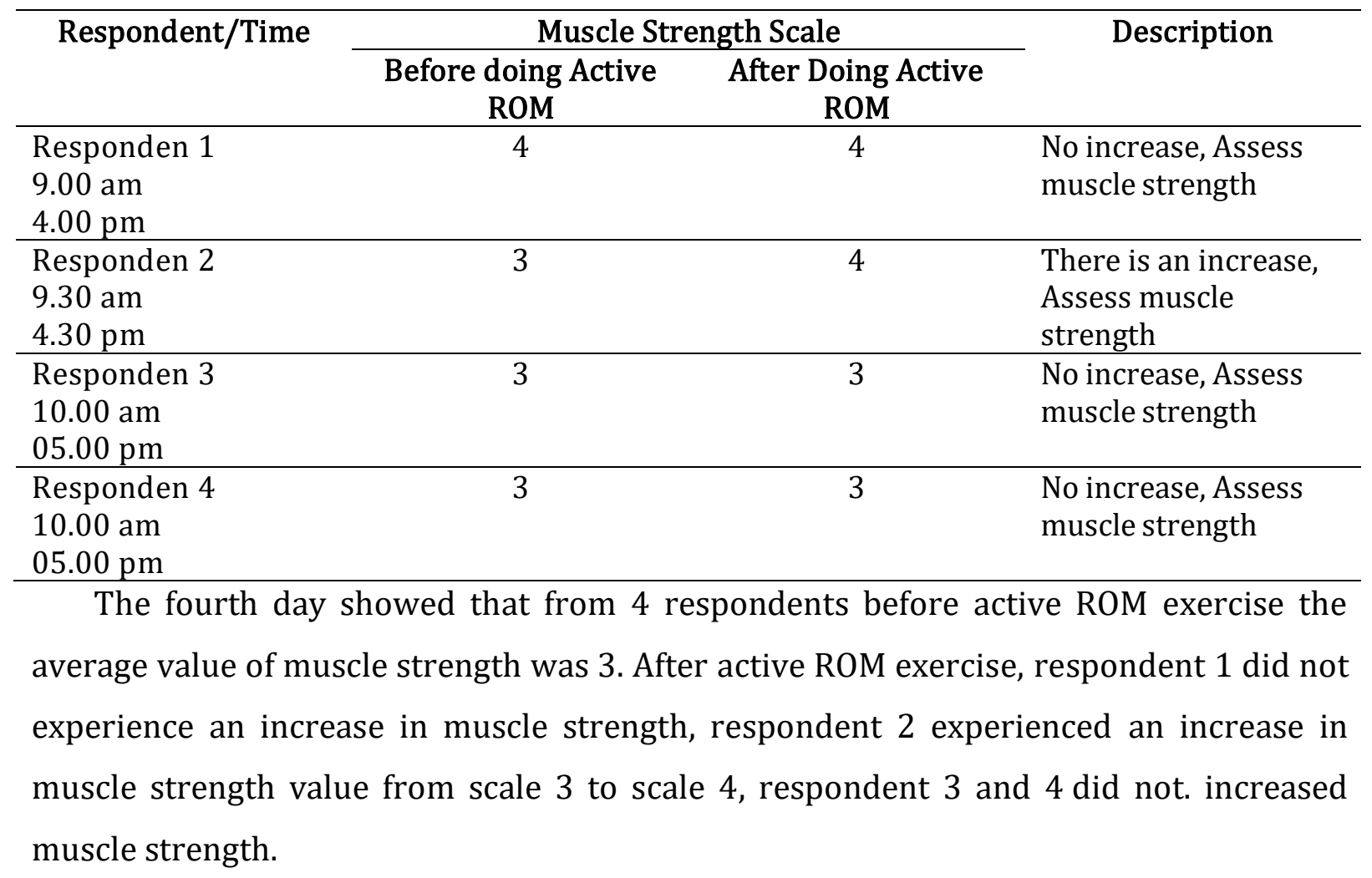


Table 6. Characteristics of Muscle Strength Scale of Respondents $(n=4)$ Before and After being givenActive ROM Intervention Exercises

\begin{tabular}{|c|c|c|c|}
\hline \multirow[t]{2}{*}{ Respondent/Time } & \multicolumn{2}{|c|}{ Muscle Strength Scale } & \multirow[t]{2}{*}{ Description } \\
\hline & $\begin{array}{c}\text { Before doing Active } \\
\text { ROM }\end{array}$ & $\begin{array}{l}\text { After Doing Active } \\
\text { ROM }\end{array}$ & \\
\hline $\begin{array}{l}\text { Responden } 1 \\
9.00 \mathrm{am} \\
4.00 \mathrm{pm} \\
\end{array}$ & 4 & 5 & $\begin{array}{l}\text { There is an increase, } \\
\text { Assess muscle } \\
\text { strength }\end{array}$ \\
\hline $\begin{array}{l}\text { Responden } 2 \\
9.30 \mathrm{am} \\
4.30 \mathrm{pm}\end{array}$ & 4 & 4 & $\begin{array}{l}\text { No increase, Assess } \\
\text { muscle strength }\end{array}$ \\
\hline $\begin{array}{l}\text { Responden } 3 \\
10.00 \mathrm{am} \\
05.00 \mathrm{pm}\end{array}$ & 3 & 4 & $\begin{array}{l}\text { There is an increase, } \\
\text { Assess muscle } \\
\text { strength }\end{array}$ \\
\hline $\begin{array}{l}\text { Responden } 4 \\
10.00 \mathrm{am} \\
05.00 \mathrm{pm}\end{array}$ & 3 & 3 & $\begin{array}{l}\text { No increase, Assess } \\
\text { muscle strength }\end{array}$ \\
\hline
\end{tabular}

The fifth day showed that from 4 respondents before active ROM exercise the average value of muscle strength 3 and 4 . After active ROM exercise, respondent 1 experienced an increase in muscle strength value from scale 4 to scale 5 , respondent 3 also experienced an increase in muscle strength value from scale 3 to 4 while respondent 2 and respondent 4 did not increase the value of muscle strength.

Table 7. Characteristics of Muscle Strength Scale of Respondents $(n=4)$ Before and After being givenActive ROM Intervention Exercises

\begin{tabular}{lccl}
\hline \multirow{2}{*}{ Respondent/Time } & \multicolumn{2}{c}{ Muscle Strength Scale } & Description \\
\cline { 2 - 3 } & $\begin{array}{c}\text { Before doing Active } \\
\text { ROM }\end{array}$ & $\begin{array}{c}\text { After Doing Active } \\
\text { ROM }\end{array}$ & \\
\hline $\begin{array}{l}\text { Responden } 1 \\
9.00 \mathrm{am}\end{array}$ & 5 & 5 & $\begin{array}{l}\text { Good Muscle } \\
\text { Strength Score }\end{array}$ \\
$4.00 \mathrm{pm}$ & & 5 & $\begin{array}{l}\text { There is an increase, } \\
\text { Assess muscle } \\
\text { strength }\end{array}$ \\
\hline $\begin{array}{l}\text { Responden } \\
9.30 \mathrm{am}\end{array}$ & 4 & & $\begin{array}{l}\text { No increase, Assess } \\
\text { muscle strength }\end{array}$ \\
$4.30 \mathrm{pm}$ & & 4 & $\begin{array}{l}\text { There is an increase, } \\
\text { Assess muscle } \\
\text { strength }\end{array}$ \\
\hline $\begin{array}{l}\text { Responden } 3 \\
10.00 \mathrm{am}\end{array}$ & 4 & & \\
$05.00 \mathrm{pm}$ & & 4 & \\
\hline Responden 4 & 3 & & \\
$10.00 \mathrm{am}$ & & & \\
$05.00 \mathrm{pm}$ & & &
\end{tabular}

The sixth day showed that from 4 respondents before active ROM exercise the average value of muscle strength was 4 . After active ROM exercise, respondent 1 had gotten a muscle strength score of 5 , respondent 2 experienced an increase in muscle strength value from a scale of 4 to a scale of 5 , respondent 3 did not exist. increase in the 
value of muscle strength, and respondent 4 experienced an increase in the value of muscle strength from a scale of 3 to 4 .

Table 8. Characteristics of Muscle Strength Scale of Respondents ( $n=4)$ Before and After being givenActive ROM Intervention Exercises

\begin{tabular}{lccl}
\hline \multirow{2}{*}{ Respondent/Time } & \multicolumn{2}{c}{ Muscle Strength Scale } & Description \\
\cline { 2 - 3 } & $\begin{array}{c}\text { Before doing Active } \\
\text { ROM }\end{array}$ & $\begin{array}{c}\text { After Doing Active } \\
\text { ROM }\end{array}$ & \\
\hline $\begin{array}{l}\text { Responden 2 } \\
9.30 \mathrm{am}\end{array}$ & 5 & 5 & $\begin{array}{l}\text { Good Muscle } \\
\text { Strength Score }\end{array}$ \\
$4.30 \mathrm{pm}$ & & 5 & $\begin{array}{l}\text { There is an } \\
\text { increase,Assess } \\
\text { mesponden } 3\end{array}$ \\
$\begin{array}{l}10.00 \mathrm{am} \\
05.00 \mathrm{pm}\end{array}$ & 4 & & $\begin{array}{l}\text { There is an } \\
\text { increase,Assess } \\
\text { muscle strength }\end{array}$ \\
\hline $\begin{array}{l}\text { Responden } 4 \\
10.00 \mathrm{am}\end{array}$ & 4 & 5 & \\
$05.00 \mathrm{pm}$ & & & \\
\hline
\end{tabular}

The seventh day showed that from 3 respondents before active ROM exercise the average value of muscle strength was 4 . After active ROM exercise was carried out, all three respondents had got a muscle strength score of 5 .

\section{DISCUSSION}

The data from the analysis of the Active Range of Motion (ROM) showed that from 4 respondents before active ROM exercise the average value of muscle strength was 2 and 3. This was because stroke patients had complications and problems, namely the occurrence of paralysis of half the body and functional disorders such as motion and sensory. This is in accordance with the concept which states that the common symptoms of stroke are paralysis of one/half of the body (hemiparesis), tingling, slanted mouth. So that stroke patients have limitations in movement (Kristiani, 2017). Hemiparesis is a common problem experienced by patients with stroke. Hemiparesis in the upper extremities can cause various limitations so that stroke patients experience a lot of dependence in activities. One of the interventions that can be done to overcome the problem of hemiparesis in the upper extremity is to do ROM exercises both passively and actively (Muttaqin, Hidayatullah \& Doewes, 2018).

The four respondents experienced paralysis of one side or half of the body (hemiparesis), Respondent 1 or Mr. 0 aged 63 years had a stroke for 6 months, before having a stroke Mr. 0 had suffered from hypertension for approximately 1 year, the client was active in seeking treatment at the Puskesmas. Mr. $\mathrm{O}$ was taught the Active 
Range of Motion when he was being treated at the Jakarta Pelni Hospital. Mr. O's muscle weakness is located in the right upper extremity, right next to the right arm until it radiates to the right shoulder and neck.

Respondent 2 or Mr. K aged 65 years had a stroke for 8 months, before having a stroke Mr. K had suffered from hypertension for approximately 3 years and also had gout for 2.5 years, the client was active in seeking treatment at the Puskesmas and taking medication. Mr. K had never been taught the Active Range of Motion movement at all. Mr. K's muscle weakness is located in the left upperextremity, precisely in the fingers up to the upper left arm.

Respondent 3 or Mrs. Z aged 60 years had a stroke for 12 months or 1 year, before having a stroke, Mrs. Z had suffered from hypertension for about 2 years and also had cholesterol for 3 years, the client was active in seeking treatment at the Puskesmas and taking medication. Mrs. Z had never been taught Active Range of Motion moves at all. Ms. Z's muscle weakness is located in the right upperextremity, precisely in the fingers up to the upper left arm and also on the left foot.

Respondent 4 or Mrs. S aged 72 years had a stroke for 1 year and 3 months, before having a stroke, Mrs. Z had suffered from diabetes mellitus for about 7 yearsand also had gout for 8 years, the client also had a history of cataract surgery. Clients are active in seeking treatment at the Puskesmas and taking drugs. Mrs. S was taught the Active Range of Motion movement while being treated at the Jakarta Pelni Hospital but was never applied again at home. Ny.S muscle weakness is located in the right and left upper extremities, precisely in the fingers up to the shoulders to the neck.

The Active Range of Motion exercise intervention will be more effective if it isdone 2 times a day with a span of 30 minutes for 7 consecutive days according to Nurtanti \& Ningrum in 2018. The first day after active ROM exercise did not experience a significant increase in muscle strength on the first day. This study is in line with Nurtanti \& Ningrum (2018) that in the assessment of limb stiffness, respondents reported that the client's muscle strength scale was of values 2 and 3.

The second day showed that from 4 respondents before active ROM exercise the average value of muscle strength 2 and 3 . After active ROM exercise did not experience a significant increase in muscle strength only respondent 3, namely from a scale of 2 to 3 . This research is in line with Mudrikhah (2018), namely Active Range of Motion 
exercises proven not only to increase muscle strength but also to maintain muscle strength, so it must take a longer time to increase the valueof the muscle strength scale.

The third day showed that from 4 respondents before active ROM exercise the average value of muscle strength 2 and 3. After active ROM exercise, respondents 1 and 2 experienced an increase in muscle strength value from scale 3 to scale 4 . Respondent 4 experienced an increase in muscle strength value from scale 2 to a scale of 3 . This research is in line with Wahyuni (2018), namely there is an increase in muscle strength on day 3, namely from a scale of 2 to 3, rehabilitation of stroke sufferers should be carried out as early as possible, such as Active Range of Motion exercises which are carried out twice a day. exercise in 30 minutes, so that there is no stiffness in the muscles.

The fourth day showed that from 4 respondents before active ROM exercise the average value of muscle strength was 3. After active ROM exercise, respondent 1 did not experience an increase in muscle strength, respondent 2 experienced an increase in muscle strength value from scale 3 to scale 4 , respondent 3 and 4 did not. increased muscle strength. According to Yudha (2019) there is an effect of Active Range of Motion (ROM) on muscle strength in the medical rehabilitation unit of dr.H. Abdoel Moeloek Lampung Province, namely an increase in the value of the muscle scale on day 4 starting from a scale of 3 to 4 .

The fifth day showed that from 4 respondents before active ROM exercise the average value of muscle strength 3 and 4 . After active ROM exercise, respondent 1 experienced an increase in muscle strength value from scale 4 to scale 5 , respondent 3 also experienced an increase in muscle strength value from scale 3 to 4 while respondent 2 and respondent 4 did not increase the value of muscle strength.

The sixth day showed that from 4 respondents before active ROM exercise the average value of muscle strength was 4 . After active ROM exercise, respondent 1 had gotten a muscle strength score of 5 , respondent 2 experienced an increase in muscle strength value from a scale of 4 to a scale of 5 , respondent 3 did not exist. increase in the value of muscle strength, and respondent 4 experienced an increase in the value of muscle strength from a scale of 3 to 4 .

The seventh day showed that of the 3 respondents before active ROM exercise the average value of muscle strength was 4 . After active ROM exercise was carried out, the 
three respondents had gotten the value of muscle strength 5. This study is in line with Kristen (2017) which shows that there is an increase in muscle strength from a scale of 4 to scale of 5 after the Active Range of Motion for 30 minutes twice a day. This shows that the more frequent the active range of motion can affect the value of muscle strength in stroke patients.

\section{CONCLUSION}

The application of the Active Range of Motion intervention has an effect on the assessment of muscle strength, as evidenced by the data on the characteristics of stroke patients, namely age, gender, and activity. Factors that rarely exercise, do not exercise repeatedly, are one of the factors that cause muscle strength to not increase. The application of the Active Range of Motion intervention in strokepatients showed an increase in the value of muscle strength, starting from the value of the muscle strength scale 2 to 3 and the scale of 3 being 4 until on the seventh day all respondents reached a scale of 5 . Changes in the value of muscle strength in the elderly stroke after being given exercise Active Range of Motion, this shows that the more often the Active Range of Motion can affect the value of muscle strength in stroke patients.

\section{SUGGESTION}

Suggestions for Health Policy Makers, for Puskesmas Jatipulo II Village can consider doing this Active ROM intervention as the management of stroke patients in the puskesmas service program. For Nursing Education Institutions, it can provide information as a reference for Active ROM nursing interventions for elderly health problems, especially stroke sufferers, the Active ROM method can beone of the materials that can be given to students to broaden their horizons in gerontic nursing interventions, especially in elderly stroke patients. For further researchers, there is a need for additional Active ROM intervention processes in the context of developing and perfecting nursing interventions in preventing stroke patients in the elderly. For families and the elderly, continue to manage the elderly independently in order to maintain their quality of life and the familycontinues to assist in continuing Active ROM interventions as an effort to prevent stroke patients in the elderly.

\section{REFERENCE}

Basuki, H. (2017). Pengaruh Akses Pelayanan Kesehatan. Buletin Penelitian Sistem Kesehatan.

Irawan \& Sondang. (2015). Metode Konvensional, Kinesiotaping Dan Motor Relearning 
Programme Berbeda Efektivitas Dalam Meningkatkan Pola Jalan Pasien Post

Stroke di Kiik Ontoseno Malang. Sport and Fitness Journal: Volume3, No. 1 : 72-133 Kementerian Kesehatan Republik Indonesia. (2017). Germas Cegah Stroke.. Diakses 19

Oktober 2020 dari : http://www.p2ptm.kemkes.go.id/artikel-sehat/germascegah-stroke

Kementerian Kesehatan Republik Indonesia. (2018). Hasil Utama Riskesdas 2018.

Diakses 18 Oktober 2020. dari :

https://kesmas.kemkes.go.id/assets/upload/dir_519d41d8cd98100/files/Hasil-

riskesdas-2018_1274.pdf

Kementerian Kesehatan Republik Indonesia. (2018). Situasi dan Analisis Lanjut Usia. Diakses 02 Februari 2021, dari Pusat Data dan Informasi : https://www.pusdatin.kemkes.go.id

Kementerian Kesehatan Republik Indonesia. (2020). Tingkatkan Kekuatan dan Daya

Tahan Otot Dengan Melakukan Latihan Fisik. Diakses 05 Januari 2021, dari:

http://www.p2ptm.kemkes.go.id/infographic-p2ptm/hipertensi-penyakit-jantungdan-pembuluh-darah/page/2/tingkatkan-kekuatan-dan-daya-tahan-otot-denganmelakukan-latihan-fisik

Kristiani, R. B. (2017). Pengaruh Range Of Motion Exercise Terhadap Kekuatan Otot Pada Pasien Stroke Di Wilayah Puskesmas Sidotopo Surabaya. Ners LENTERA Mudrikhah \& Radiansyah. (2018). Penerapan Range of Motion Aktif Terhadap Kenaikan Nilai Kekuatan Otot Lansia Penderita Stroke. Jurnal Kesehatan, Vol. 5

No. 1

Ningsih \& Nusontoro. (2019). Asuhan Keperawatan Pada Pasien Stroke Non Hemoragik Dengan Pemenuhan Kebutuhan Aktifitas dan Istirahat. Scientia Vol.6 No 1. Jakarta

Nurtanti \& Ningrum. (2018). Effektifitas Range of Motion Aktif Terhadap Peningkatan Kekuatan Otot Pada Penderita Stroke. Keperawatan GSH.

Wahyuni, R. (2018). Penerapan ROM Pada Asuhan Keperawatan Pasien Stroke Dengan Gangguan Mobilitas Fisik Di RSUD Wates Kulon Progo

World Health Organization. (2016). Stroke : a Global is Needed. Diakses 02 Januari 2021, dari: https://www.who.int/bulletin/volumes/94/9/16-181636/en/

World Health Organization. (2018). Ageing and Health. Diakses 18 Januari 2021, dari : https://www.who.int/news-room/fact-sheets/detail/ageing-and-health

Yudha, F. (2019) Pengaruh Range of Motion (ROM) Terhadap Kekuatan Otot Pasien Pasca Perawatan Stroke Di Rumah Sakit dr.H. Abdoel Moeloek Provinsi Lampung. Nursing Journal, 78-84. 